\title{
MENINJAU ZAKAT PENGHASILAN PADA FATWA MUI NO. 3 TAHUN 2003 DAN IJTIHAD YUSUF QARDHAWY
}

\author{
Muhammad Adiguna Bimasakti \\ Pengadilan Tata Usaha Negara Makassar \\ Jl. Raya Pendidikan No. 1, Makassar \\ Email:muhammad1adiguna@gmail.com
}

\begin{abstract}
The discussion on income zakat is actually quite new in the field of fiqh (Islamic Jurisprudence). Since the time of the Prophet Muhammad, this type of zakat has not been recognized because the types of professions known at that time were not as complex as it is today. Therefore, a special study is needed regarding the imposition of zakat on the types of professions that were classified as foreign at the time of the Prophet which at this time developed rapidly. Shaykh Yusuf Qaradhawy tried to discuss it and did ijtihad (Legal Finding) for this emerging problem, which he poured in his book entitled Figh Az-Zakat (Dirasah Muqaranah Li Ahkamiha wa Falsafatiha fii Dhau'al Qur'ana wa Assunnah), which means "Law of Zakat (Comparative Study Regarding the Status and Philosophy of Zakat Based on the Qur'an and Hadith) ". In Indonesia this ijtihad was adopted through the Fatwa of the Indonesian Ulama Council (MUI) on Fatwa No. 3 of 2003. However, there are things that are actually different between provisions of income zakat according to Yusuf Qaradhawy and in the MUI fatwa regarding the haul, nishab, and the basis for calculating the zakat object. This paper will try to compare these matters by looking at whether the fatwa is based on ijtihad Qaradhawy and in accordance with sharia guidelines or it creates inconsistencies in the regulation of income zakat. This paper was made with a comparative study method between Fatwa MUI No. 3 of 2003 with Ijtihad Yusuf Qaradhawy concerning Income Zakat. The things that are compared are about the elements in zakat based on Islamic law. These elements are about the basic law, nishab, haul, and the calculation of the zakat object.
\end{abstract}

Keywords: Income Zakat, Fatwa MUI No. 3 of 2003, Ijtihad of Yusuf Qaradhawy

\begin{abstract}
Abstrak
Pembahasan mengenai zakat penghasilan sebetulnya tergolong baru dalam kajian fiqh. Sejak zaman Rasulullah SAW jenis zakat ini belumlah dikenal karena jenis pekerjaan yang dikenal pada masa itu belumlah sekompleks saat ini. Oleh karena itu memang diperlukan kajian khusus mengenai pengenaan zakat terhadap jenis-jenis profesi yang tergolong asing di zaman Rasulullah yang pada masa ini berkembang pesat. Syaikh Yusuf Qaradhawy mencoba membahasnya dan melakukan ijtihad atas problem yang muncul ini, yang ia tuangkan dalam kitabnya yang berjudul Fiqh Az-Zakat (Dirasah Muqaranah Li Ahkamiha wa Falsafatiha fii Dhau'al Qur'ana wa Assunnah), yang berarti "Fiqh Zakat (Studi Komparatif
\end{abstract}


Mengenai Status Hukum dan Filsafat Zakat Berdasarkan Qur'an dan Hadis)”. Di Indonesia kemudian ijtihad ini diadopsi melalui Fatwa Majelis Ulama Indonesia (MUI) No. 3 Tahun 2003. Akan tetapi ada hal-hal yang sebetulnya berbeda antara ketentuan zakat penghasilan menurut Yusuf Qaradhawy dan dalam fatwa MUI tersebut, yakni mengenai haul, nishab, dan dasar perhitungan objek zakatnya. Tulisan ini akan mencoba mengkomparasi hal-hal tersebut dengan melihat apakah memang fatwa tersebut didasarkan pada ijtihad Qaradhawy dan sesuai dengan tuntunan syariah atau justru menimbulkan inkonsistensi pengaturan mengenai zakat penghasilan. Tulisan ini dibuat dengan metode studi komparatif antara Fatwa MUI No. 3 Tahun 2003 dengan Ijtihad Yusuf Qaradhawy mengenai Zakat Penghasilan. Hal-hal yang dibandingkan adalah mengenai unsur-unsur dalam zakat berdasarkan syariat Islam. Unsur-unsur tersebut adalah mengenai hukum dasar, nishab, haul, dan perhitungan objek zakatnya.

Kata Kunci: Zakat Penghasilan, Fatwa MUI No. 3 Tahun 2003, Ijtihad Yusuf Qaradhawy

\section{LATAR BELAKANG}

Zakat merupakan rukun Islam yang wajib dilaksanakan bagi seluruh umat Islam. Tujuan dari adanya zakat ini adalah sebagai instrumen penyeimbang dalam masyarakat antara orang yang memiliki kelebihan harta dengan orang yang kekurangan harta. Sebagaimana dikatakan oleh Muhammad Syaltut yang dikutip oleh Asmuni, Zakat merupakan wajib bagi orang yang mampu, dari harta yang berlebih dari kebutuhan dirinya dan orang-orang yang menjadi tanggungannya ${ }^{1}$.

Dalam beberapa dekade terakhir muncul pembahasan fiqh di Indonesia mengenai hukum dari zakat penghasilan atau zakat Penghasilan, yakni sejumlah zakat yang ditarik dari sebagian penghasilan yang diperoleh umat Islam. Permasalahan yang timbul adalah apakah benar hal tersebut wajib dikeluarkan mengingat secara harafiah, terminologi zakat penghasilan ini belum pernah dikenal pada zaman Nabi SAW, Sahabat, maupun Tabi'in. Hingga pada akhirnya sekitar tahun 1969 mulai muncul gagasan zakat penghasilan ini, yang ditulis oleh Syeikh

${ }^{1}$ Asmuni, Zakat penghasilan dan Upaya Menuju Kesejahteraan Sosial, Jurnal Ekonomi Islam La RIba, Vol. 1 No. 1 Juli 2017, hlm. 45. 
Yusuf Qaradhawi dalam kitabnya Fiqh Zakat, yang pertama kali terbit tahun $1969^{2}$. Judul asli dari buku ini adalah Fiqh Az-Zakat (Dirasah Muqaranah Li Ahkamiha wa Falsafatiha fii Dhau'al Qur'ana wa Assunnah), yang berarti "Fiqh Zakat (Studi Komparatif Mengenai Status Hukum dan Filsafat Zakat Berdasarkan Qur'an dan Hadis)".

Di Indonesia sendiri kajian mengenai zakat penghasilan mulai ramai sejak tahun 1990an yakni setelah kitab Yusuf Qaradhawi tersebut diterjemahkan ke dalam bahasa Indonesia oleh Didin Hafidhuddin dengan judul Fikih Zakat yang terbit tahun $1999^{3}$. Kemudian pada tahun 2003 Majelis Ulama Indonesia mengeluarkan Fatwa Nomor 3 Tahun 2003 Tentang Zakat Penghasilan yang pada dasarnya sebagian besar diambil dari kajian Yusuf Qaradhawy dari Kitab tersebut. Akan tetapi apakah dasar pengambilan hukum dan penghukuman terhadap zakat penghasilan yang digunakan dan diambil dalam Fatwa MUI No. 3 Tahun 2003 tersebut sama dengan Ijtihad Yusuf Qaradhawy dalam kitabnya tersebut? Kemudian ada suatu dalil yang melarang mensyariatkan suatu ibadah tanpa adanya perintah dari Allah maupun Rasulullah, lalu apakah memang pengenaan zakat penghasilan ini sesuai dengan tuntunan syariah dari Allah dan Rasul-Nya? Hal ini lah yang akan dibahas dalam tulisan ini.

\section{METODE PENULISAN}

Tulisan ini dibuat dengan metode studi komparatif antara Fatwa MUI No. 3 Tahun 2003 dengan Ijtihad Yusuf Qaradhawy mengenai Zakat Penghasilan. Halhal yang dibandingkan adalah mengenai unsur-unsur dalam zakat berdasarkan syariat Islam. Unsur-unsur tersebut adalah mengenai hukum dasar, nishab, haul, dan perhitungan objek zakatnya.

${ }^{2}$ Agus Marimin, dan Tira Nur Fitria, Zakat penghasilan (Zakat Penghasilan) Menurut Hukum Islam, Jurnal Ilmiah Ekonomi Islam - Vol. 01, No. 01, Maret 2015, hlm. 52.

${ }^{3}$ Ibid. 


\section{POKOK PERMASALAHAN}

Berikut ini adalah pokok permasalahan yang diangkat dalam tulisan ini berdasarkan latar belakang permasalahan di atas.

1. Apakah dasar pengambilan hukum dan penghukuman terhadap zakat penghasilan yang digunakan dan diambil dalam Fatwa MUI No. 3 Tahun 2003 tersebut sama dengan Ijtihad Yusuf Qaradhawy yang dijadikan rujukan dalam Fatwa tersebut?

2. Apakah pengenaan zakat penghasilan ini sesuai dengan tuntunan syariah Islam? 


\section{MENGENAI DEFINISI DAN HUKUM ZAKAT}

Zakat merupakan salah satu dari lima rukun Islam. Hal ini berarti zakat merupakan suatu kewajiban dari Allah SWT kepada seluruh umat Islam dengan rukun dan syarat tertentu. Mengenai kewajiban zakat, dalam sebuah hadits Rasulullah SAW bersabda sebagai berikut:

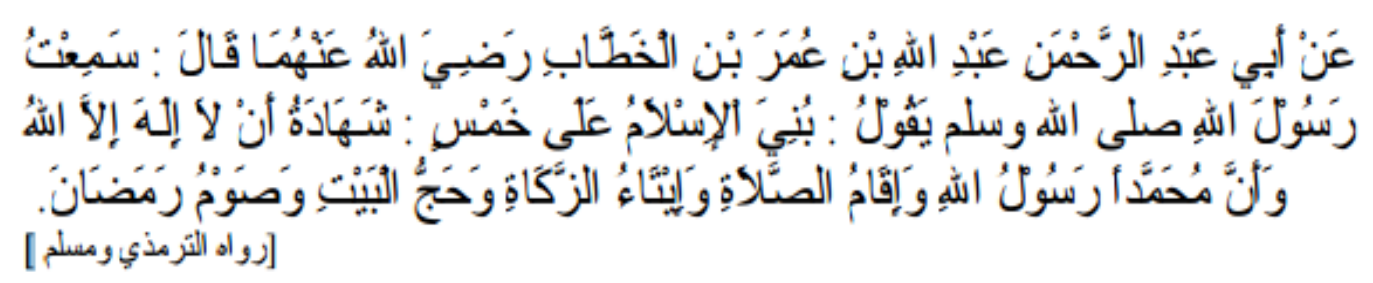

Artinya:

"Dari Abu Abdurrahman, Abdullah bin Umar bin Khattab radiallahu'anhu dia berkata : Penulis mendengar Rasulullah bersabda: Islam dibangun diatas lima perkara; Bersaksi bahwa tiada Ilah yang berhak disembah selain Allah dan bahwa nabi Muhammad utusan Allah, menegakkan shalat, menunaikan zakat, melaksanakan haji dan puasa Ramadhan." (Riwayat Tirmidzi dan Muslim) - Lihat hadits Arba'in (Imam Annawawi) Nomor 3.

Allah SWT berfirman dalam Quran Surat (QS) Annisaa: 77 sebagai berikut:

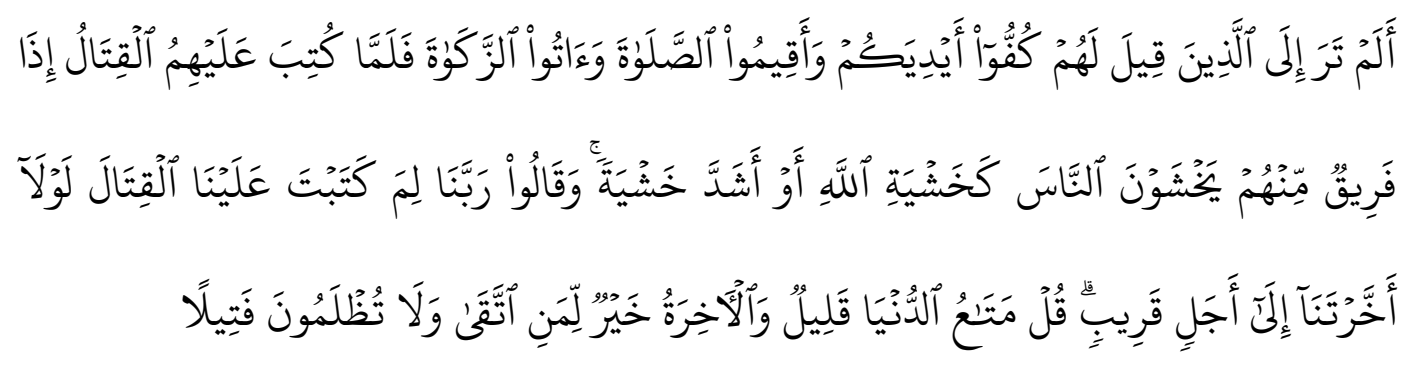

Artinya:

“77. Tidakkah kamu perhatikan orang-orang yang dikatakan kepada mereka: "Tahanlah tanganmu (dari berperang), dirikanlah sembahyang dan tunaikanlah zakat!" Setelah diwajibkan kepada mereka berperang, tiba-tiba sebahagian dari mereka (golongan munafik) takut kepada manusia (musuh), seperti takutnya kepada Allah, bahkan lebih sangat dari 
itu takutnya. Mereka berkata: "Ya Tuhan kami, mengapa Engkau wajibkan berperang kepada kami? Mengapa tidak Engkau tangguhkan (kewajiban berperang) kepada kami sampai kepada beberapa waktu lagi?" Katakanlah: "Kesenangan di dunia ini hanya sebentar dan akhirat itu lebih baik untuk orang-orang yang bertakwa, dan kamu tidak akan dianiaya sedikitpun."

Selain itu dalam QS. Attaubah ayat 103 Allah berfirman:

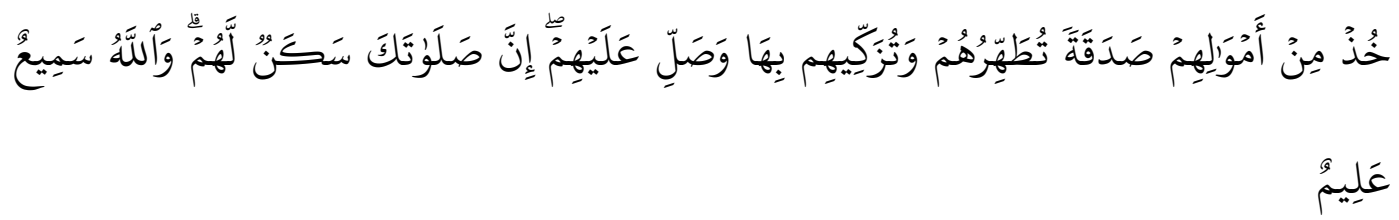

Artinya:

“103. Ambillah shadaqah dari sebagian harta mereka, dengan itu kamu membersihkan dan mensucikan mereka dan mendoalah untuk mereka. Sesungguhnya doa kamu itu (menjadi) ketenteraman jiwa bagi mereka. Dan Allah Maha Mendengar lagi Maha Mengetahui.”

Dalam Surat Attaubah ayat 103 tersebut, Allah menyebut kalimat Shadaqah untuk merujuk kepada kewajiban mengeluarkan sebagian harta dengan tujuan menyucikan (wa tuzakkiyhim bihaa). Oleh Departemen Agama kemudian terjemahan shadaqah diartikan Zakat, karena shadaqah dalam Attaubah ayat 103 tersebut bertujuan untuk menyucikan. Hal ini mengindikasikan Zakat bukanlah terminologi tetap dalam Quran melainkan sebuah Interchangeable Term atau istilah yang bisa berganti-ganti (dalam hadits pun kadang disebut zakat, kadang shadaqah) namun maknanya sama, yakni kewajiban mengeluarkan sebagian harta sepanjang dengan tujuan untuk mensucikan (diri dan harta) yang diberikan kepada golongangolongan tertentu (Vide QS. Attaubah : 60).

Secara bahasa (Lughawi) Zakat dalam bahasa arab artinya menyucikan. Sedangkan secara terminologis berarti: "Kadar Harta tertentu diberikan kepada 


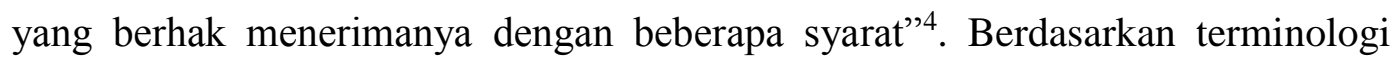
tersebut dapat ditarik beberapa unsur yakni:

1. Objek Zakat adalah harta, yakni segala kebendaan yang dimiliki oleh manusia selaku subjek hukum alamiah (Naturlijk Person);

2. Harta tersebut harus memenuhi kadar tertentu. Bisa jadi 1/10 bagian, $1 / 5$, atau 1/40 tergantung jenisnya sesuai tuntunan syariah. Dalam hal ini juga ditentukan NISHAB atau batas minimum suatu harta untuk dapat dikategorikan sebagai objek/benda zakat, dan memenuhi haul (perhitungan masa) tertentu (merujuk kepada hadits Nabi yang diriwayatkan oleh Ibnu Ummar: "Tidak ada zakat pada harta sampai berputar satu tahun (satu haul)" hadits ini juga dikutip dalam fatwa MUI No. 3 Tahun 2003 yang akan dibahas kelak);

3. Diberikan kepada orang-orang yang berhak dengan syarat tertentu (Mustahiq) - bukan bahasan kita kali ini.

Berdasarkan penjabaran tersebut dapat kita simpulkan bahwa terminologi zakat adalah digunakan untuk bentuk pengeluaran harta (nafqah/infaq) pada kadar tertentu yang sifatnya adalah kewajiban kepada golongan tertentu. selain itu klasifikasi zakat berdasarkan hadits arbain Nomor 3 tersebut di atas adalah rukun Islam yakni sebagai ibadah (mahdhoh), meskipun memiliki unsur muamalah (hubungan antar manusia). Oleh karenanya kewajiban atau syariatnya haruslah jelas dalilnya dan tidak boleh mengada-adakan yang baru tanpa hujjah yang jelas. Sebagaimana sabda Rasul SAW:

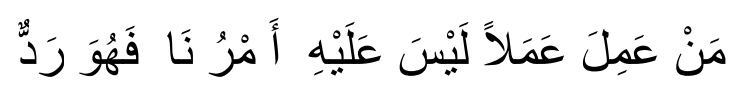

Artinya:

\footnotetext{
${ }^{4}$ Sulaiman Rasjid, Fiqh Islam, Jakarta: Attahirijah, 1957, hlm. 189.
} 
"Barangsiapa melakukan suatu amalan yang bukan berasal dari kami, maka amalan tersebut tertolak” (HR. Muslim no. 1718)

Hadits tersebut kemudian melahirkan kaidah dalam fiqh bahwa segala hal mengenai Ibadah adalah HARAM kecuali ada dalil yang memerintahkannya. Termasuk dalam konteks ibadah zakat, haruslah berdasarkan dalil perintah yang jelas baik dalam Nash Quran maupun Hadits. Jika tidak ada tuntunan perintahnya, maka amalan tersebut tertolak (sia-sia).

\section{JENIS, NISHAB DAN HAUL ZAKAT PENGHASILAN}

Berdasarkan definisi di atas, Zakat dikeluarkan dari harta yang ditentukan oleh syariat jenis, besaran, nishab dan haulnya. adapun prinsip penilaian dan perhitungan harta zakat yang harus dipenuhi adalah sebagai berikut ${ }^{5}$ :

a. Adanya Perhitungan Haul, yakni persyaratan wajib zakat untuk jenis harta tertentu yang membutuhkan perhitungan tahunan. Untuk objek zakat tertentu, harta zakat harus memenuhi ketentuan batas atau waktu yang berlaku berdasarkan syariah Islam.

b. Asas kepemilikan dengan sempurna, yakni bahwa zakat diwajibkan atas harta yang sepenuhnya dimiliki. Artinya kepemilikan dan sumber harta zakat terjamin halal sumber dan kepemilikannya.

c. Adanya Batas Minimal Harta Zakat (nishab), yakni ukuran kemampuan dalam perhitungan harta zakat yang memiliki nilai keseluruhan 85 gram emas 24 karat.

d. Zakat dikumpulkan dari laba bersih (netto), yakni zakat dikeluarkan setelah dikurangi kebutuhan dasar, menurut beberapa pendapat ijtihad ulama.

${ }^{5}$ Kementerian Agama Republik Indonesia, Petunjuk Teknis: Pengawasan, Pendampingan Audit Syariah Dan Akreditasi Lembaga Pengelola Zakat Tahun 2018, Jakarta, Direktorat Bimbingan Masyarakat Islam, Direktorat Pemberdayaan Zakat Wakaf. 
e. Penggabungan harta, yakni harta selain produk pertanian dan peternakan, menurut beberapa pendapat ijtihad ulama dapat digabungkan menjadi satu untuk efisiensi perhitungan zakat.

Menurut Yusuf Qaradhawi profesi dapat dibagi menjadi dua, yakni ${ }^{6}$ :

a. Kasbul 'amal, yakni pekerjaan yang dilakukan untuk keperluan orang lain, baik ia bekerja di pemerintahan, perusahaan, atau perorangan yang mana ia memperoleh upah. Upah yang dimaksud dapat berupa gaji dan tunjangan lain. Contohnya adalah Aparatur Sipil Negara (PNS dan Non-PNS), Pegawai Swasta, dan lain sebagainya;

b. Mihanul Hurrah, yaitu Pekerjaan Independen atau dikerjakan sendiri (bidang jasa professional). Upah yang diperoleh adalah berupa Honorarium professional. Pekerjaan ini di dalam dunia modern disebut dengan Profesi. Misalnya Advokat, Notaris, Dokter dan lain sebagainya.

Zakat Penghasilan, yang menjadi pokok bahasan dalam tulisan ini diqiyaskan oleh Majelis Ulama Indonesia melalui Fatwa Nomor 3 tahun 2003 kepada Zakat Emas dan Perak (Mata uang). Kedua jenis pekerjaan atau profesi dalam klasifikasi Yusuf Qaradhawy tersebut dapat dikenakan zakat. Zakat Penghasilan berdasarkan Fatwa MUI No. 3 Tahun 2003 tersebut diqiyaskan dengan zakat emas, yang mana hal ini dapat kita lihat berdasarkan nishabnya yakni setara dengan harga 85 gram emas. Secara umum, Allah SWT dan Rasul SAW memberikan tuntunan sebagai berikut:

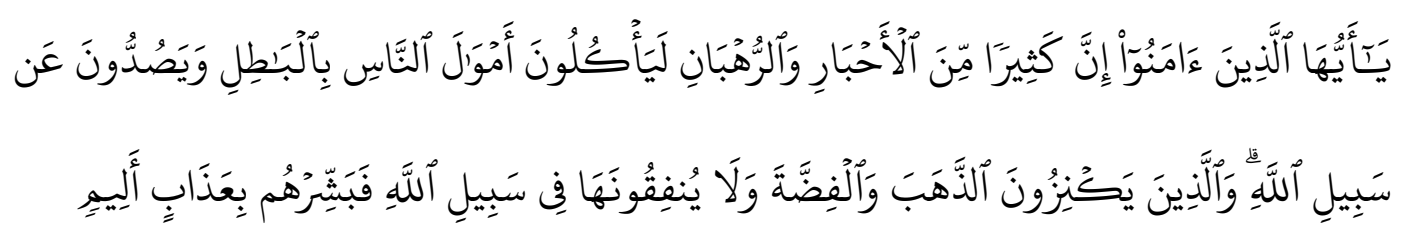

${ }^{6}$ Yusuf Qaradhawy, Fiqh Az-Zakat (Dirasah Muqaranah Li Ahkamiha wa Falsafatiha fii Dhau'al Qur'ana wa Assunnah, Beirut: Muassasah Arrisaalah, 1997, hlm. 459. 
Artinya:

34. Hai orang-orang yang beriman, sesungguhnya sebahagian besar dari orang-orang alim Yahudi dan rahib-rahib Nasrani benar-benar memakan harta orang dengan jalan batil dan mereka menghalang-halangi (manusia) dari jalan Allah. Dan orang-orang yang menyimpan emas dan perak dan tidak menafkahkannya pada jalan Allah, maka beritahukanlah kepada mereka, (bahwa mereka akan mendapat) siksa yang pedih. (QS Attaubah : 34)

Selain itu Rasul SAW bersabda:

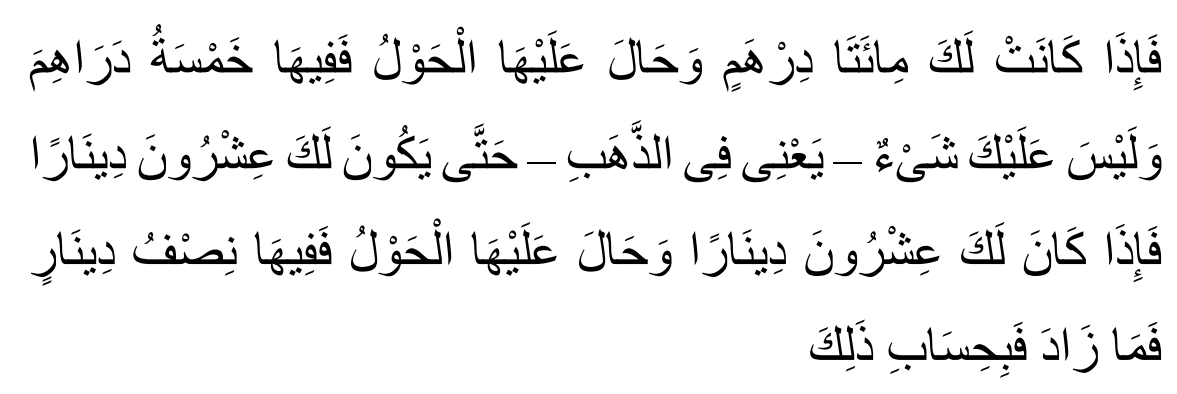

Artinya:

"Bila engkau memiliki dua ratus dirham dan telah berlalu satu tahun (sejak memilikinya), maka padanya engkau dikenai zakat sebesar lima dirham. Dan engkau tidak berkewajiban membayar zakat sedikit pun - maksudnya zakat emas- hingga engkau memiliki dua puluh dinar. Bila engkau telah memiliki dua puluh dinar, dan telah berlalu satu tahun (sejak memilikinya), maka padanya engkau dikenai zakat setengah dinar. Dan setiap kelebihan dari (nishab) itu, maka zakatnya disesuaikan dengan hitungan itu." (HR. Abu Daud no. 1573. Syaikh Al Albani mengatakan bahwa hadits ini shahih).

Berdasarkan dalil-dalil di atas, dan banyak dalil lainnya, dapat kita simpulkan bahwa untuk zakat mata uang berupa emas: 
1. Nishab dari zakat mata uang dalam hal ini emas adalah 20 Dinar (20 Mitsqal), dan zakatnya adalah 1/2 Dinar (dalam riwayat lain 1/40 bagian);

2. Benda zakat tersebut HARUSLAH TERSIMPAN selama setahun (1 haul);

3. Oleh karenanya benda zakat tersebut BUKANLAH BENDA YANG DIKONSUMSI atau digunakan untuk kebutuhan sehari-hari, melainkan BENDA SIMPANAN (Vide QS Attaubah : 34). Hal ini misalnya dapat kita lihat pada Hadits Shahih Bukhari No. 1338:

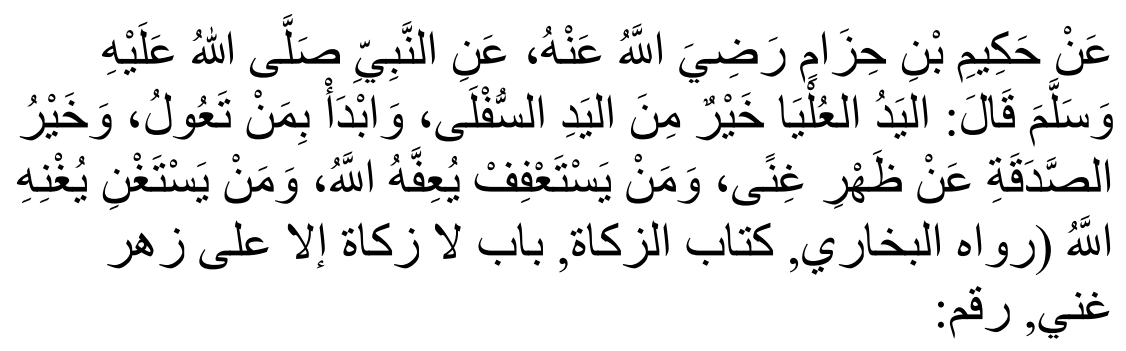

Artinya:

"Dari Hakim bin Hizam r.a., dari Nabi s.a.w., beliau bersabda: 'Tangan atas lebih baik daripada tangan bawah. Mulailah (dalam membelanjakan harta) dengan orang yang menjadi tanggung jawabmu. Sedekah paling baik adalah yang dikeluarkan dari kelebihan kebutuhan. Barang siapa berusaha menjaga diri (dari keburukan), Allah akan menjaganya. Barang siapa berusaha mencukupi diri, Allah akan memberinya kecukupan'."(HR. Bukhari: 1338).

Selain itu dapat kita lihat pula Sahih Bukhari Hadits Nomor 1371 dan Muslim No. 1631 bahwa kuda dan budak yang notabene digunakan seharihari tidak diwajibkan zakat:

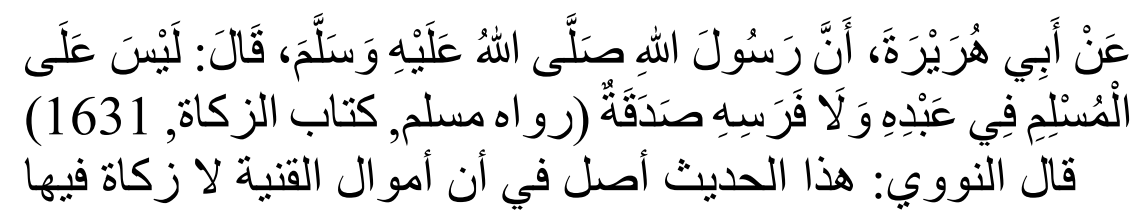


Artinya:

"Dari Abu Hurairah r.a., Rasulullah s.a.w. bersabda: 'Tidak ada zakat atas orang muslim terhadap hamba sahaya dan kudanya'.(HR. Muslim). Imam Nawawi berkata: "Hadits ini adalah dalil bahwa harta qinyah (harta yang digunakan untuk keperluan pemakaian, bukan untuk dikembangkan) tidak dikenakan zakat."7

Sedangkan pada fatwa MUI No. 3 Tahun 2003 dikatakan bahwa pada dasarnya PENGHASILAN berupa ${ }^{8}$ :

"setiap pendapatan seperti gaji, honorarium, upah, jasa, dan lainlain yang diperoleh dengan cara halal, baik rutin seperti pejabat negara, pegawai atau karyawan, maupun tidak rutin seperti dokter, pengacara,konsultan, dan sejenisnya, serta pendapatan yang diperoleh dari pekerjaan bebas lainnya."

Semua bentuk penghasilan halal tersebut wajib di keluarkan zakatnya jika telah mencapai nishab dalam haul satu tahun. Nishab yang ditentukan yakni senilai emas 85 gram dengan besaran $2.5 \%$. Oleh karenanya dapat disimpulkan bahwa Zakat Penghasilan yang dimaksud oleh Fatwa MUI No. 3 Tahun 2003 tersebut adalah hasil qiyas (analogi) dengan zakat emas. Pada Fatwa tersebut yang menjadi objek zakat adalah seluruh penghasilan tanpa melihat beban konsumsi sang Muzakki (si Wajib Zakat).

${ }^{7}$ Lihat juga: Syaikh Salim Ibn 'Ied al-Hilali, Al-Manaahisy Syar'iyyah fii Shahiihis Sunnah an-Nabawiyyah, diterjemahkan Abu Ihsan al-Atsari, Ensiklopedi Larangan menurut AlQur'an dan As-Sunnah, Jakarta: Pustaka Imam Syafi'i, 2006, hlm. 601-602.

${ }^{8}$ Majelis Ulama Indonesia, Fatwa MUI No. 3 Tahun 2003 Tentang Zakat Penghasilan, Diktum Pertama. 


\section{PERMASALAHAN DALAM ZAKAT PENGHASILAN PADA FATWA MUI} NO. 3 TAHUN 2003

\section{Mengenai Nishab Zakat Penghasilan Dalam Fatwa MUI No. 3 Tahun 2003}

Dalam fatwa tersebut dikatakan jika PENGHASILAN seorang muslim telah mencapai seharga 85 gram emas murni maka ia menjadi wajib zakat. Dalam tuntunan syariat tentunya menurut Penulis ini keliru. Karena dalam tuntunan syariat sebagaimana kita telah bahas pada bahasan kedua dalam point ketiga bahwa benda zakat tersebut bukanlah benda yang dikonsumsi atau digunakan untuk kebutuhan sehari-hari, melainkan benda simpanan (vide QS At-taubah : 34 dan Hadits Shahih Bukhari No. 1338). Oleh karena itu apabila kita ingin menarik zakat dalam penghasilan, haruslah dikurangi terlebih dahulu dari total jumlah konsumsi pada periode haulnya. Hal ini sebagaimana disampaikan Yusuf Qaradhawy dalam Bukunya Fiqh Zakat pada halaman 513 berikut:

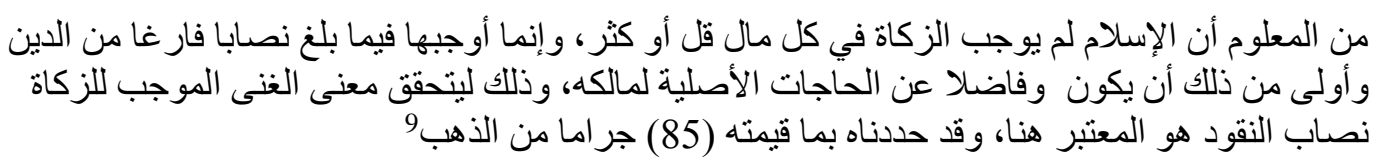

\section{Terjemah Penulis:}

"Sudah diketahui dengan baik bahwa Islam tidak membuat zakat wajib untuk semua atau sebagian besar uang (nuqud), tetapi lebih diperintahkannya ketika mencapai nisaab yang ditentukan agama dan menyimpang dari kebutuhan asli pemiliknya (alhajatal ashliyata li maalikiha), ...sehingga ketentuan zakat cukup 85 gram emas” (Fiqh Zakat, Bagian I: 513)

${ }^{9}$ Yusuf Qaradhawy, Fiqh Az-Zakat (Dirasah Muqaranah Li Ahkamiha wa Falsafatiha fii Dhau'al Qur'ana wa Assunnah, Beirut: Muassasah Arrisaalah, 1997, hlm. 513. 
Berdasarkan hal tersebut, maka penghasilan yang dapat dijadikan objek atau benda zakat hanyalah sisa dari konsumsi (kebutuhan asli pemilik harta). Setelah penghasilan tersebut digunakan untuk keperluan konsumsi barulah sisanya dihitung selama satu haul, dan jika mencukupi barulah ia wajib zakat. Oleh karena itu berdasarkan hal ini Penulis tidak sependapat dengan MUI yang menentukan objek zakat penghasilan adalah seluruh penghasilan tanpa mengurangi jatah konsumsi. Karena jatah konsumsi bukanlah benda zakat. Selain itu hutang juga merupakan kebutuhan asli sehingga hutang harus dikurangi terlebih dahulu.

Penulis ambil contoh sebagai berikut: Adi adalah seorang Pegawai Swasta memiliki penghasilan Rp. 6.000.000,- per bulan. Dalam hal ini tentu berdasarkan fatwa No. 3 / 2003 a quo penghasilan Adi tidak cukup nishab, oleh karenanya Adi harus menunggu setahun $=$ Rp. 6.000.000.- $x 12=$ Rp. 72.000.000,- sudah cukup haul dan nishab berdasarkan fatwa MUI (seharga 85 gram emas dan haul Kumulatif Satu Tahun). Hal ini menunjukkan masih bercampurnya antara konsumsi Adi selama setahun dalam penghasilan yang dijadikan objek zakat.

Pertanyaan yang timbul berkenaan dengan qiyas terhadap nishab emas adalah: berapa jumlah konsumsi Adi dalam setahun? Misal kita ambil Rp. 4.500.000,- per bulan $=$ Rp. 54.000.000,- maka sisa simpanan Adi dalam setahun adalah = Rp. 72.000.000,- dikurangi Rp. 54.000.000,- sama dengan Rp. 18.000.000,- Pertahun. Sedangkan berdasarkan kaidah nishab emas (benda simpanan) nishabnya haruslah senilai dengan 85 gram emas (saat ini kita ambil patokan Rp. 500.000,- per gram x 85= Rp. 42.500.000). Oleh karena sisa dari penghasilan Adi setelah dikurangi konsumsi setahun tidak memenuhi nishab emas maka ia tidak wajib zakat jika kita mengikuti ketentuan dalil syariat. Selain itu hal ini akan menjadi rancu ketika kita menghitung jumlah zakat yang harus dikeluarkan karena perbedaan perhitungan nishab.

2. Mengenai Haul Zakat Penghasilan Dalam Fatwa MUI No. 3 Tahun 2003 
Pada fatwa No. 3 tahun 2003 tersebut MUI juga mengatakan bahwa Zakat penghasilan dapat dikeluarkan pada saat menerima jika sudah cukup nishab. Hal ini artinya menyalahi kaidah dalam hadits bahwa: "Tidak ada zakat pada harta sampai berputar satu tahun" yang mana juga hadits tersebut dikutip dalam fatwa MUI $a q o^{10}$. Hadits ini adalah hadits marfu' yang diterima sebagai kaidah zakat. Imam Al-Ghazali sebagaimana dikutip oleh Yusuf Qaradhawy dalam Buku Fiqh Zakat tersebut menyatakan bahwa Haul zakat adalah satu tahun ${ }^{11}$, dan khusus zakat hasil pertanian haulnya adalah saat panen.

Hal ini menunjukkan pertentangan antara dalil yang dikutip dengan fatwa yang dikeluarkan oleh MUI dalam Fatwa No. 3 tahun 2003 tersebut. Zakat maal untuk emas, memiliki haul selama satu tahun (kurang lebih 354-355) hari. Jika benda zakat tersebut berada dalam penguasaan dan kepemilikan kita selama satu haul maka ia menjadi wajib zakat. Namun jika kurang dari itu ia tidak menjadi zakat.

Penulis ambil contoh sebagai berikut: Adi adalah seorang Pegawai Swasta memiliki penghasilan Rp. 6.000.000,- per bulan. Dalam hal ini tentu berdasarkan fatwa No. 3 Tahun 2003 a quo penghasilan Adi tidak cukup nishab, oleh karenanya Adi harus menunggu setahun $=$ Rp. 6.000.000.- x $12=$ Rp. 72.000.000,- sudah cukup haul dan nishab berdasarkan fatwa MUI (seharga 85 gram emas dan haul KUMULATIF SATU TAHUN).

Pertanyaan yang timbul adalah: Jika penghasilan/gaji bulan pertama berusia 354 hari (1 haul), lalu bagaimana dengan gaji bulan kedua dan seterusnya sampai keduabelas? Bukankah gaji-gaji bulan setelahnya belum satu haul? Oleh karena itu Fatwa tersebut tidak sejalan dengan kaidah haul dalam hadits. Adi baru menjadi wajib zakat apabila KELEBIHAN DARI SISA KONSUMSI di tahun tersebut disimpan selama setahun (354-355 hari). Artinya sisa penghasilan tersebut baru bisa dikeluarkan zakatnya pada tahun selanjutnya (apabila TIDAK ADA

\footnotetext{
${ }^{10}$ Bunyi hadits tersebut: الحول يحول حتى مال في زكاة لا (Laa zakaata fii maalin hatta yahuulal haul).

${ }^{11}$ Satu tahun hijriyah kurang lebih 354-355 hari.
} 
PENGURANGAN SAMA SEKALI). Begitu juga penghasilan di tahun-tahun selanjutnya. Diktum ketiga fatwa tersebut menyatakan:

- Zakat penghasilan dapat dikeluarkan pada saat menerima jika sudah cukup nishab.

- Jika tidak mencapai nishab, maka semua penghasilan dikumpulkan selama satu tahun; kemudian zakat dikeluarkan jika penghasilan bersihnya sudah cukup nishab.

\section{Ijtihad Yusuf Qaradhawy Mengenai Haul, Nishab, dan Jumlah Besaran Zakat Penghasilan}

Sebagaimana telah Penulis kemukakan di pembahasan sebelumnya bahwa Yusuf Qaradhawy berpendapat harta yang dikenakan sebagai objek zakat harus bersih dari konsumsi sang wajib zakat ${ }^{12}$. Oleh karena itu objek zakat yang diambil dari harta hendaknya dihitung nishabnya setelah dikurangi konsumsi pemilik harta dan hutang (jika ada). Barulah setelah itu dapat dihitung harta si pemilik harta ini cukup nishab atau tidak. Jika cukup nishab maka ia menjadi muzakki atau orang yang wajib zakat.

Menurut Yusuf Qaradhawy, nishab dari zakat penghasilan ini mengikuti zakat niqud/uang, yakni 85 gram emas. Dalil dari hal ini adalah qiyas atau analogi antara penghasilan dengan uang (emas/dzahabi-Dinar atau perak/fidhah-Dirham). Hal ini sebagaimana hadits berikut:

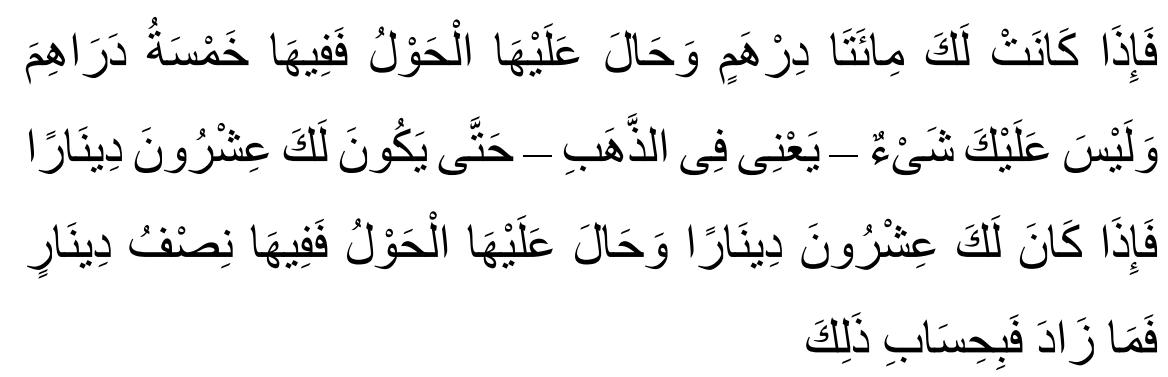

${ }^{12}$ Yusuf Qaradhawy, Fiqh Az-Zakat (Dirasah Muqaranah Li Ahkamiha wa Falsafatiha fii Dhau'al Qur'ana wa Assunnah, Beirut: Muassasah Arrisaalah, 1997, hlm. 513. 
Artinya:

"Bila engkau memiliki dua ratus dirham dan telah berlalu satu tahun (sejak memilikinya), maka padanya engkau dikenai zakat sebesar lima dirham. Dan engkau tidak berkewajiban membayar zakat sedikit pun -maksudnya zakat emas- hingga engkau memiliki dua puluh dinar. Bila engkau telah memiliki dua puluh dinar, dan telah berlalu satu tahun (sejak memilikinya), maka padanya engkau dikenai zakat setengah dinar. Dan setiap kelebihan dari (nishab) itu, maka zakatnya disesuaikan dengan hitungan itu." (HR. Abu Daud no. 1573. Syaikh Al Albani mengatakan bahwa hadits ini shahih).

Yusuf Qaradhawy kemudian mengkritik hadits ini mengenai haul objek zakat dengan mengatakan bahwa perhitungan haul atau umur satu tahun dari objek zakat adalah bermasalah. Mulai dari Perawi nya cacat (Ashim), sampai pada kesimpulan bahwa atsar mengenai haul tersebut hanya sampai kepada 'Ali Radhiyallahu'anhu ${ }^{13}$. Oleh karena itu beliau berkesimpulan haul ini tidak mutlak diterapkan pada zakat. Namun hal ini akan menimbulkan permasalahan ketika dibenturkan dengan hadits marfu' yang juga beliau kutip pada halaman 95 yang menyatakan:

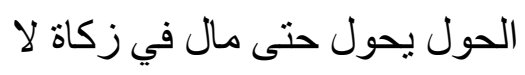

Terjemah Penulis: "Tidak ada zakat sampai berputar satu tahun"

Mengenai kadar zakat penghasilan ini beliau mengambil qiyas kepada zakat pemilik tanah yang menyewakan tanahnya untuk perkebunan yakni $2.5 \%$ dari penghasilan yang diterima. Sedangkan untuk ketentuan haulnya beliau merujuk pada zakat pertanian/hasil perkebunan yakni dikeluarkan langsung saat menerima penghasilan.

${ }^{13}$ Yusuf Qaradhawy, Fiqh Az-Zakat (Dirasah Muqaranah Li Ahkamiha wa Falsafatiha fii Dhau'al Qur'ana wa Assunnah, Beirut: Muassasah Arrisaalah, 1997, hlm. 521. 


\section{KESIMPULAN}

1. Hukum mengenai suatu objek zakat harus didasari oleh dalil naqli yang jelas dan ada tuntunan langsung dari Allah, Rasulullah, maupun para sahabat atau hal tersebut akan tertolak;

2. Yusuf Qaradhawy dalam Buku Fiqh Zakat menentukan bahwa Nishab Zakat Penghasilan diambil dari sisa konsumsi, dengan ukuran nishab zakat uang / nuqud yakni 85 gram emas. Sedangkan untuk haul, Yusuf Qaradhawy menyatakan tidak ada haul untuk zakat penghasilan karena ia sama seperti zakat penyewa tanah pertanian yang dikeluarkan setiap kali panen dengan nishab yang sama dengan zakat penyewa tanah pertanian dan nuqud yakni $2.5 \%$ dari penghasilan;

3. Zakat penghasilan menurut Yusuf Qaradhawy tidak diambil dari harta konsumsi/digunakan sehari-hari (harus berupa simpanan) melainkan sisa konsumsi yang dikumpulkan sampai senishab;

4. Permasalahan yang timbul dalam Fatwa MUI No. 3 tahun 2003 adalah mengenai Nishab penghasilan yang ternyata masih tercampur dengan harta konsumsi, dan haul yang perhitungannya tidak jelas dan tidak mengikuti tuntunan kaidah hadits mengenai haul. Yusuf Qaradhawy sudah mengantisipasi hal ini dengan memisahkan antara harta yang dikonsumsi untuk sehari-hari dengan harta zakat sehingga yang dijadikan objek zakat hanyalah sisa dari seluruh penghasilan dikurangi konsumsi.

\section{SARAN}

1. Diperlukan rumusan yang konsisten untuk penentuan hukum zakat baik dalil penerapannya, Nishabnya, Haulnya, dan tata cara perhitungannya;

2. Sebaiknya zakat penghasilan dalam Fatwa MUI No. 3 Tahun 2003 Tentang Zakat Penghasilan dalam hal mengenai nishabnya disesuaikan antara konsumsi dengan sisa penghasilan. Sehingga Nishab penghasilan yang dimaksud adalah nishab dari sisa penghasilan dan tidak bercampur konsumsi pokok serta utang yang merupakan kewajiban primer; 
3. Mengenai besaran konsumsi memang tidak akan stabil. Oleh karenanya Penulis menyarankan untuk mempermudah maka diambil saja beban konsumsi rata-rata perbulan dikalikan 12 bulan sebagai perkiraan. Atau dilihat saja sisa penghasilan yang tersisa di bulan keduabelas;

4. Islam itu tidak menyulitkan. Namun juga harus diingat batasan mana saja yang tidak boleh diterabas.

\section{DAFTAR PUSTAKA}

\section{Buku}

Ibn 'Ied al-Hilali, Syaikh Salim. Al-Manaahisy Syar'iyyah fii Shahiihis Sunnah an-Nabawiyyah, diterjemahkan Abu Ihsan al-Atsari, Ensiklopedi Larangan menurut Al-Qur'an dan As-Sunnah, Jakarta: Pustaka Imam Syafi'i, 2006

Kementerian Agama Republik Indonesia, Petunjuk Teknis: Pengawasan, Pendampingan Audit Syariah Dan Akreditasi Lembaga Pengelola Zakat Tahun 2018, Jakarta, Direktorat Bimbingan Masyarakat Islam, Direktorat Pemberdayaan Zakat Wakaf.

Rasjid, Sulaiman. Fiqh Islam. Jakarta: Attahirijah, 1957.

Yusuf Qaradhawy, Fiqh Az-Zakat (Dirasah Muqaranah Li Ahkamiha wa Falsafatiha fii Dhau'al Qur'ana wa Assunnah, Beirut: Muassasah Arrisaalah, 1997, hlm. 459.

\section{Artikel Jurnal}

Asmuni. Zakat penghasilan dan Upaya Menuju Kesejahteraan Sosial. Jurnal Ekonomi Islam La RIba, Vol. 1 No. 1 Juli 2017, hlm. 43-56.

Marimin, Agus dan Tira Nur Fitria. Zakat penghasilan (Zakat Penghasilan) Menurut Hukum Islam, Jurnal Ilmiah Ekonomi Islam - Vol. 01, No. 01, Maret 2015, hlm. 50-60.

\section{Fatwa}

Majelis Ulama Indonesia, Fatwa MUI No. 3 Tahun 2003 Tentang Zakat Penghasilan.. 